\title{
Martelella mediterranea gen. nov., sp. nov., a novel $\alpha$-proteobacterium isolated from a subterranean saline lake
}

Correspondence

Raúl Rivas

raul@wwwedu-micro.usal.es

\author{
Raúl Rivas, ${ }^{1}$ Salud Sánchez-Márquez, ${ }^{2}$ Pedro F. Mateos, ${ }^{1}$ \\ Eustoquio Martínez-Molina ${ }^{1}$ and Encarna Velázquez ${ }^{1}$ \\ ${ }^{1}$ Departamento de Microbiología y Genética, Lab. 209, Edificio Departamental de Biología, \\ Universidad de Salamanca, Campus M. Unamuno, 37007 Salamanca, Spain \\ ${ }^{2}$ Instituto de Recursos Naturales y Agrobiología, CSIC, Salamanca, Spain
}

\begin{abstract}
A bacterial strain was isolated from the water of Lake Martel in Mallorca (Spain). The isolate, designated MACL $11^{\top}$, was halotolerant and strictly aerobic. The cells were non-motile, non-spore-forming, Gram-negative short rods. Comparative 16S rRNA gene sequence analysis revealed that MACL $11^{\top}$ represents a separate line of descent within the order 'Rhizobiales' of the class 'Alphaproteobacteria'. Strain MACL $11^{\top}$ was most closely related to the genera Rhizobium (93.3\% sequence similarity to Rhizobium rhizogenes), Aurantimonas (90.3\% sequence similarity to Aurantimonas coralicida) and Fulvimarina ( $90 \cdot 3 \%$ sequence similarity to Fulvimarina pelagi). Chemotaxonomically, strain $\mathrm{MACL} 11^{\top}$ was characterized by the presence of $\mathrm{Q}-10$ as the major respiratory lipoquinone. The major fatty acids detected were $\mathrm{C}_{19}$ :0 cyclo $\omega 8 c, \mathrm{C}_{18: 1} \omega 7 c, \mathrm{C}_{16: 0}$ and 11-methyl $\mathrm{C}_{18: 1} \omega 7 c$. The $\mathrm{G}+\mathrm{C}$ content of the DNA was $57.4 \mathrm{~mol} \%$. Oxidase and catalase activities were present. Growth with many different carbohydrates as the sole carbon source was observed. The data from this polyphasic study suggest that this bacterium belongs to a novel genus of the order 'Rhizobiales' and is not associated with any of the known families of this order. It is proposed that isolate MACL $11^{\top}$ should be classified in a novel genus and species, Martelella mediterranea gen. nov., sp. nov., with MACL $11^{\top}\left(=\right.$ LMG $22193^{\top}=$ CECT $\left.5861^{\top}\right)$ as the type strain.
\end{abstract}

In recent years, increasing interest in micro-organisms from saline environments has led to the discovery of novel species and genera belonging to the order 'Rhizobiales', such as Roseibium (Suzuki et al., 2000), Aurantimonas (Denner et al., 2003) and Fulvimarina (Cho \& Giovannoni, 2003). They were all retrieved from marine environments; none of them was isolated from saline lakes. Here, we describe the characterization of a strain belonging to a novel genus of the order 'Rhizobiales' that was isolated from water collected at Lake Martel, a subterranean saline lake in Mallorca, Spain. Lake Martel is $177 \mathrm{~m}$ long, approximately $30 \mathrm{~m}$ wide and approximately 5-12 $\mathrm{m}$ deep and contains semisalt water. The temperature of the water remains constant at $18{ }^{\circ} \mathrm{C}$ and its $\mathrm{pH}$ is about $7 \cdot 5$.

Strain MACL11 ${ }^{\mathrm{T}}$ was isolated under aseptic conditions from water samples taken from Lake Martel at a depth of $10 \mathrm{~cm}$. A $200 \mathrm{ml}$ sample was filtered under vacuum in

Published online ahead of print on 18 November 2004 as DOI 10.1099/ijs.0.63438-0.

The GenBank/EMBL/DDBJ accession number for the almost-complete 16S rRNA gene sequence of strain MACL $11^{\top}$ is AY649762. sterile conditions through a membrane filter (Millipore) with a pore diameter of $45 \mu \mathrm{m}$. The membrane was placed on a plate containing YED medium $(0.5 \%$ yeast extract, $0.7 \%$ glucose, $2 \%$ agar) supplemented with $5 \%($ w/v) $\mathrm{NaCl}$ and was incubated at $28{ }^{\circ} \mathrm{C}$. The colony morphology was examined in cultures grown on YED medium supplemented with $5 \%(\mathrm{w} / \mathrm{v}) \mathrm{NaCl}$.

Strain MACL $11^{\mathrm{T}}$ was grown on YED medium $(0 \cdot 5 \%$ yeast extract, $0.7 \%$ glucose, $1.5 \%$ agar) for $48 \mathrm{~h}$ to check for motility by phase-contrast microscopy (Axioskop 2; Zeiss). Gram staining was carried out using the procedure described by Doetsch (1981). Cells were gently suspended in sterile distilled water, stained with $0 \cdot 2 \%$ uranyl acetate and examined at $80 \mathrm{kV}$ using a Zeiss EM 209 transmission electron microscope (Peix et al., 2003).

Cells of strain MACL1 $11^{\mathrm{T}}$ were Gram-negative, non-motile short $\operatorname{rods}(1 \cdot 0-1 \cdot 1 \times 1 \cdot 3-1 \cdot 5 \mu \mathrm{m})$ (Fig. 1). Colonies were white- to cream-coloured on YED medium. They were smooth and mostly flat. Morphologically, strain MACL $11^{\mathrm{T}}$ was different from related genera (Table 1).

Physiological and biochemical tests were performed using 


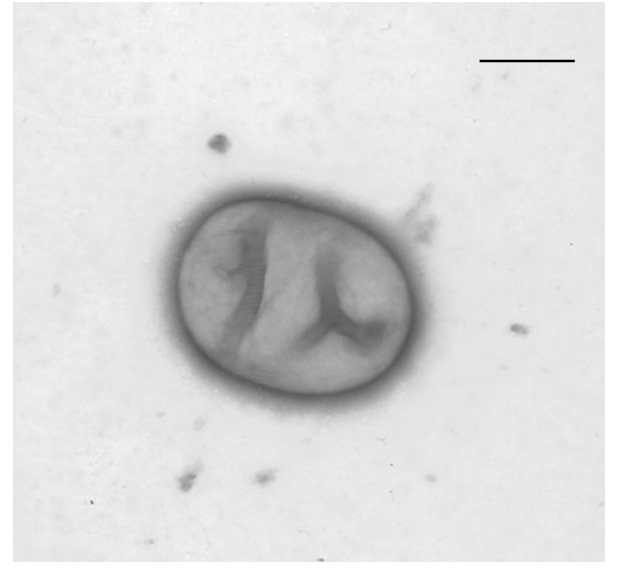

Fig. 1. Electron micrograph of strain $M A C L 11^{\top}$, grown on nutrient agar (Difco/Becton Dickinson) $\left(48 \mathrm{~h}, 22^{\circ} \mathrm{C}\right)$, showing coccobacillary morphology. Bar, $0.57 \mu \mathrm{m}$.

the API 20NE, API 20E and API ZYM strips (bioMérieux), according to the manufacturer's instructions and were incubated at $28{ }^{\circ} \mathrm{C}$ (testing must be performed in conventional format and for at least $72 \mathrm{~h}$ ). Tests of enzyme activity for caseinase, catalase and oxidase were performed as described previously (Rivas et al., 2003). The temperature range for growth was determined by incubating cultures in YED medium between 4 and $45^{\circ} \mathrm{C}$. The $\mathrm{pH}$ range was determined in YED medium with a final $\mathrm{pH}$ between $4 \cdot 0$ and $10 \cdot 0$. Salt tolerance was studied in YED medium containing $0-20 \%(\mathrm{w} / \mathrm{v}) \mathrm{NaCl}$.

Differentiating phenotypic characteristics of strain MACL11 ${ }^{\mathrm{T}}$ with respect to closely related genera are shown in Table 1. According to these data, this strain differs from members of the genus Rhizobium as regards growth at $40{ }^{\circ} \mathrm{C}$, hydrolysis of aesculin and growth with $5 \% \mathrm{NaCl}$, D-arabinose, citrate, D-mannose, D-sorbitol and sucrose. Strain MACL $11^{\mathrm{T}}$ is different from members of the genus Aurantimonas in terms of growth without $\mathrm{NaCl}$, hydrolysis of aesculin and growth with D-arabinose, citrate, mannitol, D-mannose, D-sorbitol and sucrose. Finally, isolate MACL1 $11^{\mathrm{T}}$ differs from the genus Fulvimarina in terms of growth at $40{ }^{\circ} \mathrm{C}$, hydrolysis of aesculin and growth with $10 \% \mathrm{NaCl}, \mathrm{D}$-arabinose, D-mannose and sucrose. Strain MACL1 $11^{\mathrm{T}}$ grew optimally at $28^{\circ} \mathrm{C}$ (growth range $4-37^{\circ} \mathrm{C}$; no growth at $\left.40^{\circ} \mathrm{C}\right)$ and $\mathrm{pH} 7 \cdot 0(\mathrm{pH}$ range $5-8 \cdot 5)$. Strain MACL $11^{\mathrm{T}}$ grew optimally at $\mathrm{NaCl}$ concentrations

Table 1. Characteristics that differentiate the genus Martelella gen. nov. from related genera

Genera: 1, Martelella gen. nov.; 2, Rhizobium; 3, Aurantimonas; 4, Fulvimarina. Data are from Tighe et al. (2000), Young et al. (2001), Cho \& Giovannoni (2003), Denner et al. (2003) and this study. Symbols: +, positive; -, negative; v, variable; ND, not detected.

\begin{tabular}{|c|c|c|c|c|}
\hline Characteristic & 1 & 2 & 3 & 4 \\
\hline Morphology & Short rods & Rods & Rods & Short rods \\
\hline Division type & Binary fission & Binary fission & Branching division & Binary fission \\
\hline Motility & - & + & + & - \\
\hline Growth without $\mathrm{NaCl}$ & + & + & - & + \\
\hline \multicolumn{5}{|l|}{ Growth at/in: } \\
\hline $40^{\circ} \mathrm{C}$ & - & $\mathrm{V}$ & - & + \\
\hline $5 \% \mathrm{NaCl}$ & + & - & ND & + \\
\hline $10 \% \mathrm{NaCl}$ & - & - & ND & + \\
\hline Hydrolysis of aesculin & + & $\mathrm{V}$ & - & - \\
\hline Production of pigments & - & - & + & + \\
\hline \multicolumn{5}{|l|}{ Utilization of carbohydrates: } \\
\hline D-Arabinose & - & + & - & + \\
\hline Citrate & - & + & - & ND \\
\hline Mannitol & + & + & - & + \\
\hline D-Mannose & - & + & + & + \\
\hline D-Sorbitol & - & + & - & - \\
\hline Sucrose & - & $\mathrm{V}$ & - & + \\
\hline Predominant cellular fatty acids & $\begin{array}{c}\mathrm{C}_{19: 0} \text { cyclow8c }(41 \cdot 4 \%) \\
\mathrm{C}_{18: 1} \omega 7 c(21 \cdot 6 \%), \mathrm{C}_{16: 0}(12 \%) \\
\text { 11-methyl } \mathrm{C}_{18: 1} \omega 7 c(8 \cdot 8 \%)\end{array}$ & $\begin{array}{l}\text { Summed feature } 7^{*} \\
(24-68 \%), \mathrm{C}_{19: 0} \\
\text { cyclo } \omega 8 c(3-50 \%)\end{array}$ & $\begin{array}{c}\mathrm{C}_{18: 1} \omega 7 c(76 \cdot 9 \%) \\
\mathrm{C}_{19: 0} \text { cyclo } \omega 8 c \\
(10 \cdot 5 \%)\end{array}$ & $\begin{array}{c}\mathrm{C}_{18: 1} \omega 7 c(82 \cdot 9 \%) \\
\mathrm{C}_{18: 0}(8 \cdot 2 \%)\end{array}$ \\
\hline Other minor fatty acids & $\begin{array}{c}\mathrm{C}_{18: 0}, 10-\text { methyl } \mathrm{C}_{19: 0} \\
\mathrm{C}_{20: 2} \omega 6,9 c, \mathrm{C}_{18: 0} 3-\mathrm{OH} \\
\mathrm{C}_{16: 0} 3-\mathrm{OH}\end{array}$ & $\begin{array}{c}\mathrm{C}_{16: 0}, \mathrm{C}_{16: 0} 3-\mathrm{OH} \\
\mathrm{C}_{17: 0}, \mathrm{C}_{18: 0} \\
\mathrm{C}_{20: 3} \omega 6,9,12 c\end{array}$ & $\begin{array}{c}\mathrm{C}_{16: 0}, \mathrm{C}_{16: 1} \omega 7 c \\
\mathrm{C}_{18: 0}, \mathrm{C}_{17: 0}, \mathrm{C}_{20: 1} \omega 7 c \\
\mathrm{C}_{18: 1} 2-\mathrm{OH}\end{array}$ & $\begin{array}{c}\mathrm{C}_{16: 0}, \mathrm{C}_{16: 1} \omega 7 c, \mathrm{C}_{18: 1} \\
\text { 2-OH, } \mathrm{C}_{18: 0} \\
\text { 3-OH, } \mathrm{C}_{19: 0} \omega 8 c, \mathrm{C}_{20: 1} \omega 7 c\end{array}$ \\
\hline DNA $G+C$ content $(\mathrm{mol} \%)$ & $57 \cdot 4$ & $57-66$ & $66 \cdot 3$ & $57 \cdot 6-59 \cdot 9$ \\
\hline
\end{tabular}

${ }^{\star}$ Summed feature 7 comprises $18: 1 \omega 7 c / \omega 9 t / \omega 12 t$ and/or $18: 1 \omega 7 c / \omega 9 c / \omega 12 t$. 
of up to $2 \%$ and it also grew in the presence of $\mathrm{NaCl}$ concentrations up to $5 \%(\mathrm{w} / \mathrm{v})$, although salt was not essential for growth.

Determinations of lipoquinones and cellular fatty acid composition were performed as described by Zimmermann et al. (1998).

Ubiquinones were the only respiratory lipoquinones detected: Q-10 predominated (98\%), although Q-9 was present in minor amounts $(2 \%)$. This quinone profile is characteristic of most species within the class 'Alphaproteobacteria' (Collins \& Jones, 1981; Yokota et al., 1992; Busse et al., 1999).

The cellular fatty acid profile of MACL11 ${ }^{\mathrm{T}}$ was characterized by 15 different fatty acids. The major fatty acids detected in strain MACL1 $1{ }^{\mathrm{T}}$ were $\mathrm{C}_{19: 0}$ cyclo $\omega 8 c(41 \cdot 44 \%)$, $\mathrm{C}_{18: 1} \omega 7 c(21 \cdot 66 \%), \mathrm{C}_{16: 0} \quad(12.04 \%)$ and 11-methyl $\mathrm{C}_{18: 1} \omega 7 c(8 \cdot 84 \%)$. Additional fatty acids detected included summed feature 2 (7.68\%; comprising $\mathrm{C}_{14: 0} 3-\mathrm{OH}$, iso$\mathrm{C}_{16: 1} \mathrm{I}$, an unidentified fatty acid with an equivalent chain-length of $10 \cdot 928$ and/or $\mathrm{C}_{12: 0}$ ALDE), $\mathrm{C}_{18: 0}(4 \cdot 29 \%)$, 10 -methyl $\mathrm{C}_{19: 0}(1 \cdot 08 \%), \mathrm{C}_{20: 2} \omega 6,9 c(0 \cdot 70 \%), \mathrm{C}_{18: 0} 3$ $\mathrm{OH}(0.68 \%)$, summed feature $3(0.63 \%$; comprising $\mathrm{C}_{16: 1} \omega 7 c$ and/or iso- $\left.\mathrm{C}_{15: 0} 2-\mathrm{OH}\right), \mathrm{C}_{16: 0} 3-\mathrm{OH}(0 \cdot 52 \%)$ and an unidentified fatty acid with an equivalent chainlength of $14.959(0.44 \%)$. According to published data, significant amounts of a $\mathrm{C}_{19: 0}$ cyclo $\omega 8 \mathrm{c}$ fatty acid are typical of members of the order 'Rhizobiales' (Wilkinson, 1988; Moreno et al., 1990; Jarvis et al., 1996; Dunfield et al., 1999; Kämpfer et al., 1999; Tighe et al., 2000). The fatty acid $\mathrm{C}_{20: 3} \omega 6,9,12 c$, which is detected in all species of the genus Rhizobium, is not present in strain MACL11 ${ }^{\mathrm{T}}$. Another difference between strain MACL11 ${ }^{\mathrm{T}}$ and members of the genus Rhizobium is the presence of 11-methyl $\mathrm{C}_{18: 1} \omega 7 \mathrm{c}$ in the former. The fatty acids 11-methyl $\mathrm{C}_{18: 1} \omega 7 c$ and 10methyl $\mathrm{C}_{19: 0}$ detected in strain MACL1 $11^{\mathrm{T}}$ are not present in members of the genera Aurantimonas and Fulvimarina. Moreover, strain MACL $11^{\mathrm{T}}$ was clearly differentiated from members of the genera Rhizobium, Aurantimonas and Fulvimarina in terms of the proportions of several fatty acids (Tighe et al., 2000; Cho \& Giovannoni, 2003; Denner et al., 2003).

DNA for $\mathrm{G}+\mathrm{C}$ content determination was prepared according to the method of Chun \& Goodfellow (1995). The $\mathrm{G}+\mathrm{C}$ content of the DNA (mol\%) was determined using the thermal denaturation method (Mandel \& Marmur, 1968): the value for strain MACL11 ${ }^{\mathrm{T}}$ was found to be $57 \cdot 4 \mathrm{~mol} \%$. This value is similar to those obtained for members of the genera Fulvimarina and Rhizobium.

For 16S rRNA gene sequencing, DNA extraction was carried out as described previously (Rivas et al., 2001). 16S rRNA gene amplification and sequencing were performed according to the methods described previously (Rivas et al., 2003). An almost-complete 16S rRNA gene sequence was obtained and then compared with those deposited in the GenBank database. Sequences were aligned using CLUSTAL X software (Thompson et al., 1997). Distances were calculated according to the methods of Jukes \& Cantor (1969), Kimura (1980), Tamura \& Nei (1984) and Tajima \& Nei (1993). Phylogenetic trees were inferred using the neighbourjoining method (Saitou \& Nei, 1987), minimum evolution (Rzhetsky \& Nei, 1993) and parsimony analysis (Felsenstein, 1983). Bootstrap analysis was based on 1000 resamplings. The MEGA2 package (Kumar et al., 2001) was used for all analyses.

On the basis of the 16S rRNA gene sequence analysis, the organism under study belongs to the order 'Rhizobiales' of the class 'Alphaproteobacteria'. A comparison against the sequences held in GenBank indicated that the strain was most closely related to the genera Rhizobium (93.3\% similarity to Rhizobium rhizogenes IFO $13257^{\mathrm{T}}$ ), Aurantimonas (90.4 \% similarity to Aurantimonas coralicida DSM $14790^{\mathrm{T}}$ ) and Fulvimarina $(90.3 \%$ similarity to Fulvimarina pelagi HTCC2506 ${ }^{\mathrm{T}}$ ). Fig. 2 shows the phylogenetic placement of strain MACL11 ${ }^{\mathrm{T}}$ within the order 'Rhizobiales'. The same results were obtained when the phylogenetic distances were calculated using the Jukes-Cantor one-parameter, the Kimura two-parameter, the Tamura-Nei three-parameter and the Tajima-Nei four-parameter methods. The three methods for obtaining phylogenetic trees (using the four above-mentioned methods with each to calculate phylogenetic distances), i.e. neighbour-joining, minimum evolution and parsimony analyses, also afforded the same results (data not shown). As shown in the phylogenetic tree (Fig. 2), strain MACL $11^{\mathrm{T}}$ formed a separate branch within the order 'Rhizobiales' that was not significantly associated with any of the known families of this order; this relationship was supported by a high bootstrap value (98\%). Thus, phylogenetically, this novel genus probably belongs a novel family within the order 'Rhizobiales'.

Overall, the results of the present study, i.e. the low similarity value for the $16 \mathrm{~S}$ rRNA sequence together with differences found in chemotaxonomic, morphological and physiological analyses, indicate that isolate MACL $11^{\mathrm{T}}$ should be classified within a novel genus as a novel species, for which we propose the name Martelella mediterranea gen. nov., sp. nov.

\section{Description of Martelella gen. nov.}

Martelella (Mar.tel'ell.a. N.L. fem. dim. n. Martelella in honour of the French explorer E. Martel, who, in 1896, discovered Lake Martel inside the caves of Drach in Mallorca, the site where this micro-organism was isolated).

Cells are Gram-negative, non-spore-forming short rods. Strictly aerobic. Oxidase- and catalase-positive. Phylogenetically related to members of the order 'Rhizobiales'. The only respiratory lipoquinones present are ubiquinones, Q-10 predominating. The most abundant fatty acids are $\mathrm{C}_{19: 0}$ cyclo $\omega 8 c, \mathrm{C}_{18: 1} \omega 7 c, \mathrm{C}_{16: 0}$ and 11-methyl $\mathrm{C}_{18: 1} \omega 7 c$. The other minor fatty acids are $\mathrm{C}_{18: 0}, 10$-methyl $\mathrm{C}_{19: 0}$, 


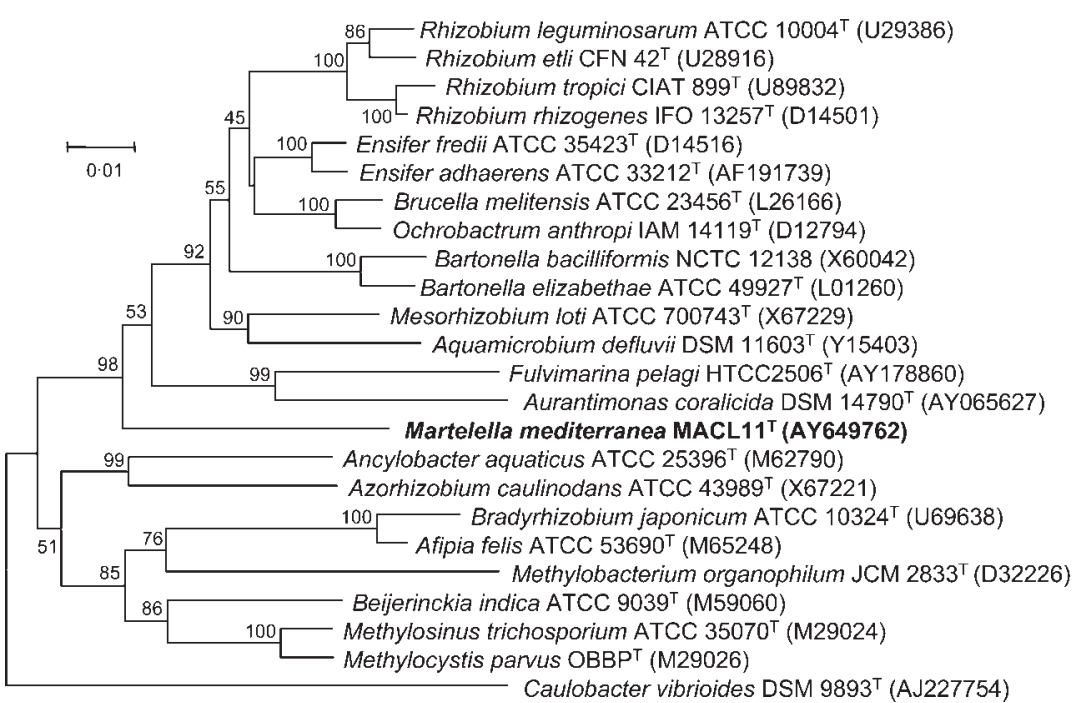

Fig. 2. Neighbour-joining tree based on nearly-complete $16 \mathrm{~S}$ rRNA gene sequences of Martelella mediterranea MACL $11^{\top}$ and other related organisms of the order 'Rhizobiales'. The significance of each branch is indicated by a bootstrap percentage calculated for 1000 subsets. Bar, 1 substitution per 100 nt.
$\mathrm{C}_{20: 2} \omega 6,9 c, \mathrm{C}_{18: 0} 3-\mathrm{OH}$ and $\mathrm{C}_{16: 0} 3-\mathrm{OH}$. The DNA G+C content of the type species is $57.4 \mathrm{~mol} \%$. The type species of the genus is Martelella mediterranea.

\section{Description of Martelella mediterranea sp. nov.}

Martelella mediterranea [me.di.ter.ra.ne'a. L. fem. adj. mediterranea inland (used to refer to the Mediterranean Sea), referring to the fact that the type strain was isolated from a Mediterranean island].

Displays the following properties in addition to those given in the genus description. Cells are non-motile coccobacillary rods, $1 \cdot 0-1 \cdot 1 \times 1 \cdot 3-1 \cdot 5 \mu \mathrm{m}$ in size. Colonies on YED medium supplemented with $5 \%(\mathrm{w} / \mathrm{v}) \mathrm{NaCl}$ are circular, smooth, opaque, white- to cream-coloured pigmented colonies that are usually $1-3 \mathrm{~mm}$ in diameter within 5 days at $28^{\circ} \mathrm{C}$. Grows in the presence of $\mathrm{NaCl}$ concentrations up to $5 \%(\mathrm{w} / \mathrm{v})$, although salt is not essential for growth. The temperature range for growth is $4-37^{\circ} \mathrm{C}$ (optimal growth occurs at $28^{\circ} \mathrm{C}$ ) and the $\mathrm{pH}$ range for growth is $5-8 \cdot 5$ (optimal growth occurs at $\mathrm{pH} 7$ ). Ureasepositive. Indole is not produced. Aesculin is hydrolysed. Positive in the Voges-Proskauer reaction and for nitrate reduction. The type strain utilizes gluconate, glucose, malate, maltose and mannitol as sole carbon sources, and does not grow in adipate, amygdalin, arabinose, caproate, citrate, inositol, mannose, melibiose, $\mathrm{N}$-acetylglucosamine, phenylacetate, rhamnose, sorbitol or sucrose. The type strain actively produces $\beta$-galactosidase, alkaline phosphatase, esterase (C4), esterase lipase (C8), lipase (C14), leucine arylamidase, valine arylamidase, cystine arylamidase, trypsin, acid phosphatase, $\alpha$-galactosidase, $\beta$-glucuronidase, $\alpha$-gluconidase, $\beta$-gluconidase and $N$-acetyl- $\beta$-glucosaminidase. It does not produce gelatinase, caseinase, arginine dihydrolase, lysine decarboxylase, ornithine decarboxylase, chymotrypsin, naphthol-AS-BI-phosphohydrolase, $\alpha$-mannosidase, $\alpha$-fucosidase or $\mathrm{H}_{2} \mathrm{~S}$.

The type strain is MACL11 ${ }^{\mathrm{T}}\left(=\mathrm{LMG} 22193^{\mathrm{T}}=\mathrm{CECT}\right.$
$5861^{\mathrm{T}}$ ), isolated from a water sample from a subterranean saline lake on Mallorca, Spain.

\section{Acknowledgements}

This work was supported by the Comisión Interministerial de Ciencia y Tecnología-Dirección General de Educatión Superior and the Junta de Castilla y León (Spanish Government). We are grateful to the DSMZ staff for chemotaxonomic analyses. We thank Dr J. Gónzalez and M. Ortíz-Aranda for their help with the electron microscopy preparations.

\section{References}

Busse, H.-J., Kämpfer, P. \& Denner, E. B. M. (1999). Chemotaxonomic characterisation of Sphingomonas. J Ind Microbiol Biotechnol 23, 242-251.

Cho, J.-C. \& Giovannoni, S. J. (2003). Fulvimarina pelagi gen. nov., sp. nov., a marine bacterium that forms a deep evolutionary lineage of descent in the order 'Rhizobiales'. Int J Syst Evol Microbiol 53, 1853-1859.

Chun, J. \& Goodfellow, M. (1995). A phylogenetic analysis of the genus Nocardia with $16 \mathrm{~S}$ rRNA gene sequences. Int J Syst Bacteriol 45, 240-245.

Collins, M. D. \& Jones, D. (1981). Distribution of isoprenoid quinone structural types in bacteria and their taxonomic implications. Microbiol Rev 45, 316-354.

Denner, E. B. M., Smith, G. W., Busse, H.-J., Schumann, P., Narzt, T., Polson, S. W., Lubitz, W. \& Richardson, L. L. (2003). Aurantimonas coralicida gen nov., sp. nov., the causative agent of white plague type II on Caribbean scleractinian corals. Int J Syst Evol Microbiol 53, $1115-1122$.

Doetsch, R. N. (1981). Determinative methods of light microscopy. In Manual of Methods for General Bacteriology, pp. 21-33. Edited by P. Gerhardt, R. G. E. Murray, R. N. Costilow, E. W. Nester, W. A. Wood, N. R. Krieg \& G. B. Phillips. Washington, DC: American Society for Microbiology.

Dunfield, K. E., Xavier, L. J. C. \& Germida, J. J. (1999). Identification of Rhizobium leguminosarum and Rhizobium sp. (Cicer) strains using a custom fatty acid methyl ester (FAME) profile library. I Appl Microbiol 86, 78-86. 
Felsenstein, J. (1983). Parsimony in systematics: biological and statistical issues. Annu Rev Ecol Syst 14, 313-333.

Jarvis, B. D. W., Sivakumaran, S., Tighe, S. W. \& Gillis, M. (1996). Identification of Agrobacterium and Rhizobium species based on cellular fatty acid composition. Plant Soil 184, 143-158.

Jukes, T. H. \& Cantor, C. R. (1969). Evolution of protein molecules. In Mammalian Protein Metabolism, vol. 3, pp. 21-132. Edited by H. N. Munro. New York: Academic Press.

Kämpfer, P., Müller, C., Mau, M., Neef, A., Auling, G., Busse, H.-J., Osborn, A. M. \& Stolz, A. (1999). Description of Pseudaminobacter gen. nov. with two new species, Pseudaminobacter salicylatoxidans sp. nov. and Pseudaminobacter defluvii sp. nov. Int J Syst Bacteriol 49, 887-897.

Kimura, M. (1980). A simple method for estimating evolutionary rates of base substitutions through comparative studies of nucleotide sequences. J Mol Evol 16, 111-120.

Kumar, S., Tamura, K., Jakobsen, I. B. \& Nei, M. (2001). MEGA2: molecular evolutionary genetics analysis software. Bioinformatics 17, 1244-1245.

Mandel, M. \& Marmur, J. (1968). Use of ultraviolet absorbance temperature profile for determining the guanine plus cytosine content of DNA. Methods Enzymol 12B, 195-206.

Moreno, E., Stackebrandt, E., Dorsch, M., Wolters, J., Busch, M. \& Mayer, H. (1990). Brucella abortus $16 \mathrm{~S}$ rRNA and lipid A reveal a phylogenetic relationship with members of the alpha-2 subdivision of the class Proteobacteria. J Bacteriol 172, 3569-3576.

Peix, A., Rivas, R., Mateos, P. F., Martínez-Molina, E., RodríguezBarrueco, C. \& Velázquez, E. (2003). Pseudomonas rhizosphaerae sp. nov., a novel species that actively solubilizes phosphate in vitro. Int J Syst Evol Microbiol 53, 2067-2072.

Rivas, R., Velázquez, E., Valverde, A., Mateos, P. F. \& MartínezMolina, E. (2001). A two primers random amplified polymorphic DNA procedure to obtain polymerase chain reaction fingerprints of bacterial species. Electrophoresis 22, 1086-1089.

Rivas, R., Sánchez, M., Trujillo, M. E., Zurdo-Piñeiro, J. L., Mateos, P. F., Martínez-Molina, E. \& Velázquez, E. (2003). Xylanimonas cellulosilytica gen. nov., sp. nov., a xylanolytic bacterium isolated from a decayed tree (Ulmus nigra). Int J Syst Evol Microbiol 53, 99-103.

Rzhetsky, A. \& Nei, M. (1993). Theoretical foundation of the minimum-evolution method of phylogenetic inference. Mol Biol Evol 10, 1073-1095.
Saitou, N. \& Nei, M. (1987). The neighbor-joining method: a new method for reconstructing phylogenetic trees. Mol Biol Evol 4, 406-425.

Suzuki, T., Muroga, Y., Takahama, M. \& Nishimura, Y. (2000). Roseibium denhamense gen. nov., sp. nov. and Roseibium hamelinense sp. nov., aerobic bacteriochlorophyll-containing bacteria isolated from the east and west coasts of Australia. Int J Syst Evol Microbiol 50, 2151-2156.

Tajima, F. \& Nei, M. (1984). Estimation of evolutionary distance between nucleotide sequences. Mol Biol Evol 1, 269-285.

Tamura, K. \& Nei, M. (1993). Estimation of the number of nucleotide substitutions in the control region of mitochondrial DNA in humans and chimpanzees. J Mol Evol 10, 512-526.

Thompson, J. D., Gibson, T. J., Plewniak, F., Jeanmougin, F. \& Higgins, D. G. (1997). The CLUSTAL_X Windows interface: flexible strategies for multiple sequence alignment aided by quality analysis tools. Nucleic Acids Res 25, 4876-4882.

Tighe, S. W., de Lajudie, P., Dipietro, K., Lindström, K., Nick, G. \& Jarvis, B. D. W. (2000). Analysis of cellular fatty acids and phenotypic relationships of Agrobacterium, Bradyrhizobium, Mesorhizobium, Rhizobium and Sinorhizobium species using the Sherlock Microbial Identification System. Int J Syst Evol Microbiol 50, 787-801.

Wilkinson, S. G. (1988). Gram-negative bacteria. In Microbial Lipids, vol. 1, pp. 299-487. New York: Academic Press.

Yokota, A., Akagawa-Matsushita, M., Hiraishi, A., Katayama, Y., Urakami, T. \& Yamasato, K. (1992). Distribution of quinone systems in microorganisms: gram-negative eubacteria. Bull Jpn Fed Cult Coll 8, 136-171.

Young, J. M., Kuykendall, L. D., Martínez-Romero, E., Kerr, A. \& Sawada, H. (2001). A revision of Rhizobium Frank 1889, with an emended description of the genus, and the inclusion of all species of Agrobacterium Conn 1942 and Allorhizobium undicola de Lajudie et al. 1998 as new combinations: Rhizobium radiobacter, R. rhizogenes, R. rubi, R. undicola and R. vitis. Int J Syst Evol Microbiol 51, 89-103.

Zimmermann, O., Spröer, C., Kroppenstedt, R. M., Fuchs, E., Köchel, H. G. \& Funke, G. (1998). Corynebacterium thomssenii sp. nov., a Corynebacterium with $N$-acetyl- $\beta$-glucosaminidase activity from human clinical specimens. Int J Syst Bacteriol 48, $489-494$. 